\title{
Improving the Electrical Parameters of a Photovoltaic Panel by Means of an Induced or Forced Air Stream
}

\author{
R. Mazón-Hernández, J. R. García-Cascales, F. Vera-García, A. S. Káiser, and B. Zamora \\ Department of Thermal and Fluids Engineering, Technical University of Cartagena, Doctor Fleming s/n, 30202 Cartagena, Spain
}

Correspondence should be addressed to R. Mazón-Hernández; rocio.mazon@upct.es

Received 16 January 2013; Accepted 20 February 2013

Academic Editor: Vincenzo Augugliaro

Copyright (C) 2013 R. Mazón-Hernández et al. This is an open access article distributed under the Creative Commons Attribution License, which permits unrestricted use, distribution, and reproduction in any medium, provided the original work is properly cited.

\begin{abstract}
The main priority in photovoltaic (PV) panels is the production of electricity. The transformation of solar energy into electricity depends on the operating temperature in such a way that the performance increases with the decreasing temperatures. In the existing literature, different cooling techniques can be found. The purpose of most of them is to use air or water as thermal energy carriers. This work is focused on the use of air as a working fluid whose movement is either induced by natural convection or forced by means of a fan. The aim of this study is to characterise the electrical behaviour of the solar panels in order to improve the design of photovoltaic installations placed in roof applications ensuring low operating temperatures which will correct and reverse the effects produced on efficiency by high temperature. To do this, a test installation has been constructed at the Universidad Politécnica de Cartagena in Spain. In this paper, the results of the tests carried out on two identical solar panels are included. One of them has been modified and mounted on different channels through which air flows. The different studies conducted show the effects of the air channel cross-section, the air velocity, and the panel temperature on the electrical parameters of the solar panels, such as the voltage, current, power, and performance. The results conclude that the air space between the photovoltaic panels and a steel roof must be high enough to allow the panel to be cooled and consequently to achieve higher efficiency.
\end{abstract}

\section{Introduction}

Photovoltaic cells allow the direct conversion of solar energy into electrical energy with maximum efficiency at around 9$12 \%$, depending on the type of solar cell. More than $80 \%$ of the solar radiation reaching the photovoltaic cell is not converted into electricity; it is reflected or transformed into heat energy.

The heat generated induces an increase in the cell temperature and consequently a decrease in the efficient conversion of electricity. The high temperature has a negative effect on the electrical output parameters of the PV panels. The electrical efficiency and hence the power output of a PV panel depend on the operating temperature, which decrease with its temperature, so their conversion efficiency degrades by about $0.4-0.5 \%$ per degree rise in temperature (see Brinkworth et al. [1]). So, the operating temperature plays a key role in the photovoltaic conversion process. According to Angrist [2], Hu and White [3], or Graff and Fischer [4], this inverse relationship of output power conversion efficiency with temperature is mainly due to the dependence of the open circuit voltage, $V_{\mathrm{oc}}$, on the temperature. Therefore, a lot of authors have studied different cooling techniques in PV panels $[5,6]$. Most of them are based on the use of an energy carrier, usually air $[7,8]$ or water [9-11].

The unfavourable effect of temperature increase on the performance of the panel is an important factor to take into account. In this study, we analyse the behaviour of PV panels at high temperature whilst using different cooling configurations. The most popular applications of PV panels are in open fields to produce electricity; nowadays, panels are also placed on the roofs of houses, industrial buildings and, recently, greenhouses built for growing mushrooms and ornamental plants that do not require much sunlight. In these latter cases, the problem of high temperature and decreased power is worse, due to the fact that space between both surfaces (the PV panels and the plastic roof) is smaller and consequently there is less cooling effect by natural convection. The effect of the temperature on the performance has been 
analysed by testing different cooling configurations at natural and forced convection using a fan with a set of nozzles, both varying the space of the open air channel provided underneath the panel.

As mentioned before, the use of air as thermal energy carrier to cool photovoltaic panels can be done by using either a "chimney effect" provoked by natural convection or forced convection through a driven air duct. An example of this type of study is in Tiwari et al. [8], where a duct with a fan was at the rear surface of the panel.

This work presents the experimental installation developed to study different geometries of air ducts. It was already introduced in Mazón-Hernández et al. [12]. A detailed description of the sensors used and an uncertainty analysis of the different measured and calculated variables may be found there and some preliminary results obtained for different cross-section and considering an induced air flow were also shown. In the present work, new data which also includes the effect of the forced air velocity is considered. This is achieved by forcing the air circulation by means of a fan. In the following sections, the installation is briefly described. The results obtained for the different cross-sections in the cases of natural-induced circulation and forced circulation are included. The effect of using different configurations on the photovoltaic panel performance is shown. Some conclusions and a brief description of the studies still ongoing are shown.

\section{Experimental Facility}

The solar installation which has been used to obtain the experimental results consists of two photovoltaic panels arranged as shown in Figure 1. A first panel (left panel as panel A) is in normal conditions to be used as a reference. The other panel (panel B) has been placed above a steel plate, with an air channel underneath the panel, varying in spacing (Figure 1(a)). With this configuration we have collected the result at natural convection. With these results, we can analyse, on the one hand, the panel behaviour when it is placed on the steel roof of an industrial building and, on the other hand, the influence of the temperature depending on the space between both surfaces. This panel has also been tested with forced convection, using a fan that has been connected by means of a nozzle (Figure 1(b)).

Panel temperature at different points, voltage, and current are measured to understand the panel behaviour under normal operating conditions and to compare with the other one (panel B), which is modified to test different ducts with different cross-sections. In this second panel, panel temperature at different points, voltage, and current are also measured together with the air temperature and the air flow rate through the channel.

\section{Description of the Instrumentation Used}

The main features of the sensors used in the installation are shown in Table 1 . The PV panel temperatures are measured with five flexible resistance temperature detectors (RTD), which are attached to the back of the panel $\left(T_{\text {panel, }, 1}, T_{\text {panel,2 }}\right.$,
TABLE 1: Sensors description.

\begin{tabular}{|c|c|}
\hline Sensor model & Characteristics \\
\hline \multirow{4}{*}{$\begin{array}{l}\text { B Class } \\
\text { Precision } \\
\text { Pt100 Probes }\end{array}$} & (i) Measure the temperature of the panel \\
\hline & (ii) Manufacturer: TC direct \\
\hline & (iii) Range: $-50-150^{\circ} \mathrm{C}$ \\
\hline & (iv) Accuracy: $\pm 0.5100^{\circ} \mathrm{C}$ \\
\hline \multirow{4}{*}{$\begin{array}{l}\text { A Class } \\
\text { Precision } \\
\text { Pt100 Probes }\end{array}$} & (i) Measure the temperature of the air flow \\
\hline & (ii) Manufacturer: TC direct \\
\hline & (iii) Range: $-50-250^{\circ} \mathrm{C}$ \\
\hline & (iv) Accuracy: $\pm 0.3600^{\circ} \mathrm{C}$ \\
\hline \multirow{4}{*}{$\begin{array}{l}\text { Hot Film } \\
\text { Anemome- } \\
\text { ters } \\
\text { EE66-C }\end{array}$} & (i) Measure the air velocity, natural convection \\
\hline & (ii) Manufacturer: E+E electronik \\
\hline & (iii) Range: $0-2 \mathrm{~m} / \mathrm{s}$ \\
\hline & (iv) Accuracy: $\pm(0.06 \mathrm{~m} / \mathrm{s}+2 \%)$ \\
\hline \multirow{4}{*}{$\begin{array}{l}\text { Hot Film } \\
\text { Anemome- } \\
\text { ters } \\
\text { EE65-C }\end{array}$} & (i) Measure the air velocity, forced convection \\
\hline & (ii) Manufacturer: E+E electronik \\
\hline & (iii) Range: $0-20 \mathrm{~m} / \mathrm{s}$ \\
\hline & (iv) Accuracy: $\pm(0.2 \mathrm{~m} / \mathrm{s}+3 \%)$ \\
\hline \multirow{3}{*}{$\begin{array}{l}\text { Precision } \\
\text { Pyranometer } \\
\text { PSP }\end{array}$} & (i) Measure the global radiation \\
\hline & $\begin{array}{l}\text { (ii) Manufacturer: EPPLEY Precision Spectral } \\
\text { Pyranometer (PSP) }\end{array}$ \\
\hline & (iii) Range: $0-1200 \mathrm{~W} / \mathrm{m}^{2}$ \\
\hline \multirow{6}{*}{$\begin{array}{l}\text { Electronik } \\
\text { Load }\end{array}$} & (i) Electronic governor \\
\hline & (ii) Obtain the $I-V$ characteristic curve \\
\hline & $\begin{array}{l}\text { (iii) Manufacturer: Universidad Politécnica de } \\
\text { Cartagena }\end{array}$ \\
\hline & (iv) Range: $0-100 \mathrm{~V}$ \\
\hline & $0-10 \mathrm{~A}$ \\
\hline & (v) Accuracy: $\begin{aligned} & \pm 5 \mathrm{mV} \\
& \pm 5.4 \mathrm{~mA}\end{aligned}$ \\
\hline \multirow{9}{*}{$\begin{array}{l}\text { Data Logger } \\
34980 \mathrm{~A}\end{array}$} & (i) Data acquisition system \\
\hline & (ii) Collect and register data \\
\hline & (iii) Manufacturer: Agilent \\
\hline & $\begin{array}{l}\text { (iv) Accuracy (\%reading }+\% \text { range): } \\
\text { Depending on type of input }\end{array}$ \\
\hline & Temperature sensors: $\pm 0.0060^{\circ} \mathrm{C}$ \\
\hline & Anemometers: $0.0050 \%+0.0005 \%$ \\
\hline & PV Panel voltage: $0.0035 \%+0.0005 \%$ \\
\hline & PV Panel current: $0.0050 \%+0.0005 \%$ \\
\hline & Pyranometer: $0.0050 \%+0.0005 \%$ \\
\hline
\end{tabular}

$T_{\text {panel, } 3}, T_{\text {panel,4 }}$, and $\left.T_{\text {panel,5 }}\right)$. In order to measure the temperature of the air flow inside the channel, we also used RTD, in two different locations, at the inlet $\left(T_{\mathrm{air}, i, 1}, T_{\mathrm{air}, i, 2}\right)$ and the outlet of the air duct $\left(T_{\mathrm{air}, o, 1}, T_{\mathrm{air}, o, 1}\right)$. The air velocity inside the channel is measured with two hot film anemometers, which are located near the air outlet $\left(v_{\text {air }, 1}, v_{\text {air }, 2}\right)$. The electrical variables are measured using a variable load or electrical regulator to achieve the characteristic curves of each panel. The pyranometer measures the solar radiation, being placed parallel to the PV panel. Other environmental 


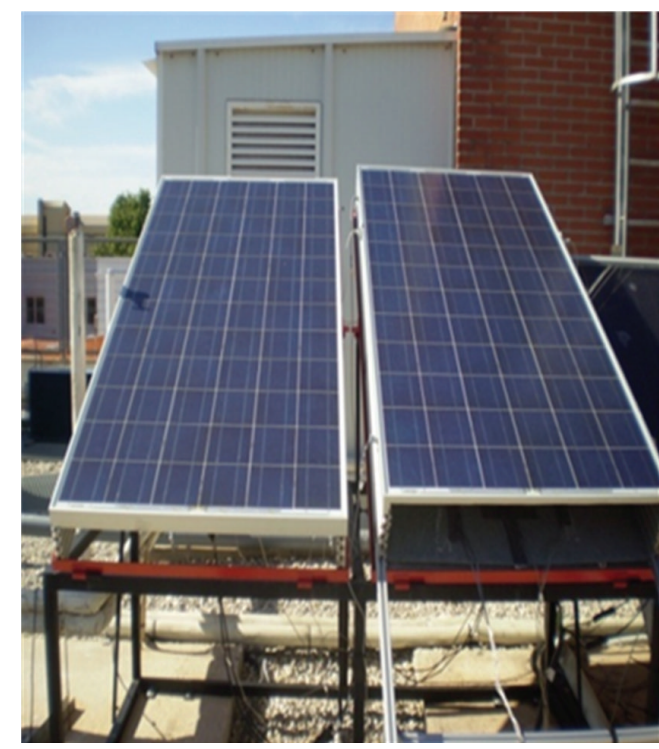

(a)

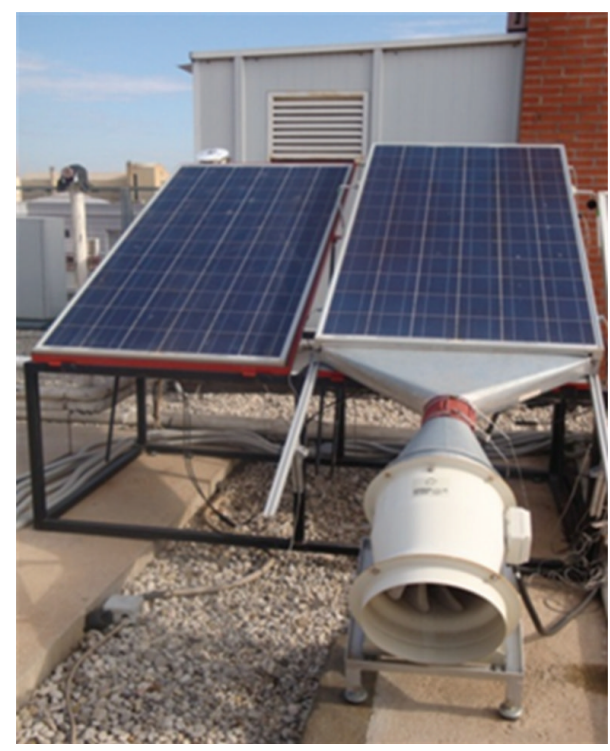

(b)

FIGURE 1: Solar experimental facility. Left panel labelled as panel A is not modified and the right panel labelled as panel B is above a steel plate, creating an air channel underneath it. (a) Natural convection configuration. (b) Forced convection configuration.

conditions such as temperature, pressure, and wind speed are measured by a meteorological station placed just beside the experimental facility. All data are registered and recorded by means of a data logger.

Considering the uncertainty analysis carried out in Mazón-Hernández et al.s paper [12], the uncertainties in the measured and calculated variables are those shown in Table 2.

\section{Experimental Analysis of the Temperature Influence on the Electrical Variables for Different Configurations}

To study the influence of panel temperature and the aspect ratio of the air channel on the panel performance, several experimental cases have been made for different configurations. The panels used have been provided by the company Apia XXI, which has supported us throughout our research. They have set up different photovoltaic fields in the south of Spain and also photovoltaic greenhouses in the last year, using the same panels. The specifications of the panels are shown in Figure 2.

Several trials have been carried out to compare the behaviour of the panels with different configurations. When only natural convection is considered, then the experimental data has been collected at different aspect ratios changing the channel width, which is the space of air underneath the panel, $(0.105,0.135,0.165 \mathrm{~m})$ and when forced convection is considered, we have also tested for these aspect ratios and for different fan-induced velocities $(2,3$, and $4 \mathrm{~m} / \mathrm{s})$. All possible combinations have been studied.

A data logger has allowed us to record the electrical variables $\left(I_{\mathrm{mp}}, V_{\mathrm{mp}}, V_{\mathrm{oc}}, I_{\mathrm{sc}}\right)$ and the variables $\left(T_{\text {panel }}\right.$, $\left.T_{\text {air }}, V_{\text {air }}, I_{\text {pyra }}\right)$. Once they have been obtained, the peak power and the efficiency (at the maximum power point) of each panel have been calculated by using the following equations:

$$
\begin{gathered}
P=I_{\mathrm{mp}} \cdot V_{\mathrm{mp}}, \\
\eta=\frac{P_{m}}{I_{\mathrm{rr}}}=\frac{I_{\mathrm{mp}} \cdot V_{\mathrm{mp}}}{I_{\mathrm{pyra}} \cdot S_{\text {panel }}} .
\end{gathered}
$$

4.1. Methodology for Data Collection. The data of all variables has been collected every hour, from $8.30 \mathrm{~h}$ to $15.30 \mathrm{~h} \mathrm{GMT}+1$, with different sunny days for each configuration. In this way, we have studied and analysed the measured results throughout the sunny days, under similar environmental conditions.

The procedure carried out to obtain the values of all variables each hour consists of collecting 10 samples of measures during a period of 25 seconds. If the environmental conditions keep similar during the test, the value of each variable is calculated as the mean of the measured samples.

The results shown in the figures correspond to similar days with same level of radiation, ambient temperature, humidity, and so forth, in order to compare them. All of them were registered in July and August 2011.

4.2. Natural Convection Cases: Effects of the Aspect Ratio. The electrical behaviour of a PV panel when it is placed on the roof of an industrial building is affected by panel temperature because there is little space below the panel to be cooled by natural convection. We have tested it out, collecting and comparing the measured results from both panels, that panel A works isolated as a reference panel (without any plate underneath) and panel B is placed above a steel plate leaving a space between both surfaces (Figure 3). This configuration 
ET module

ET-P672280 ET-P672270 $\quad$ ET-P672260 $\quad$ ET-P672250 ET-P672240

Specifications

\begin{tabular}{|c|c|c|c|c|c|}
\hline Model type & ET-P672280 & ET-P672270 & ET-P672260 & ET-P672250 & ET-P672240 \\
\hline Peak power $\left(P_{m}\right)$ & $280 \mathrm{~W}$ & $270 \mathrm{~W}$ & $260 \mathrm{~W}$ & $250 \mathrm{~W}$ & $240 \mathrm{~W}$ \\
\hline Cell type & \multicolumn{5}{|c|}{ Polycrystalline silicon, $156 \mathrm{~mm} \times 156 \mathrm{~mm}$} \\
\hline Number of cells & \multicolumn{5}{|c|}{72 cells in series } \\
\hline Weight & \multicolumn{5}{|c|}{$23.0 \mathrm{~kg}(50.7 \mathrm{lbs})$} \\
\hline Dimensions & \multicolumn{5}{|c|}{$1956 \times 992 \times 50 \mathrm{~mm}(77 \times 39.1 \times 2$ inch $)$} \\
\hline Maximum power voltage $\left(V_{\mathrm{mp}}\right)$ & $36.72 \mathrm{~V}$ & $36.40 \mathrm{~V}$ & $36.00 \mathrm{~V}$ & $35.20 \mathrm{~V}$ & $34.95 \mathrm{~V}$ \\
\hline Maximum power current $\left(I_{\mathrm{mp}}\right)$ & $7.63 \mathrm{~A}$ & $7.42 \mathrm{~A}$ & $7.23 \mathrm{~A}$ & $7.12 \mathrm{~A}$ & $6.88 \mathrm{~A}$ \\
\hline Open circuit voltage $\left(V_{o c}\right)$ & $43.78 \mathrm{~V}$ & $43.63 \mathrm{~V}$ & $43.49 \mathrm{~V}$ & $43.20 \mathrm{~V}$ & $43.20 \mathrm{~V}$ \\
\hline Short circuit current $\left(I_{\mathrm{sc}}\right)$ & $8.30 \mathrm{~A}$ & $8.10 \mathrm{~A}$ & $7.79 \mathrm{~A}$ & $7.70 \mathrm{~A}$ & $7.60 \mathrm{~A}$ \\
\hline Maximum system voltage & \multicolumn{5}{|c|}{$\mathrm{DC} 1000 \mathrm{~V}$} \\
\hline Temp. coeff. of $I_{\mathrm{sc}}\left(\mathrm{TK} I_{\mathrm{sc}}\right)$ & \multicolumn{5}{|c|}{$0.09 \% /{ }^{\circ} \mathrm{C}$} \\
\hline Temp. coeff. of $V_{\mathrm{oc}}\left(\mathrm{TK} V_{\mathrm{oc}}\right)$ & \multicolumn{5}{|c|}{$-0.34 \% /^{\circ} \mathrm{C}$} \\
\hline Temp. coeff. of $P_{m}\left(\right.$ TK $\left.P_{m}\right)$ & \multicolumn{5}{|c|}{$-0.37 \% /{ }^{\circ} \mathrm{C}$} \\
\hline Normal operating cell temperature & \multicolumn{5}{|c|}{$44.4 \pm 2^{\circ} \mathrm{C}$} \\
\hline
\end{tabular}

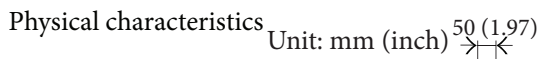
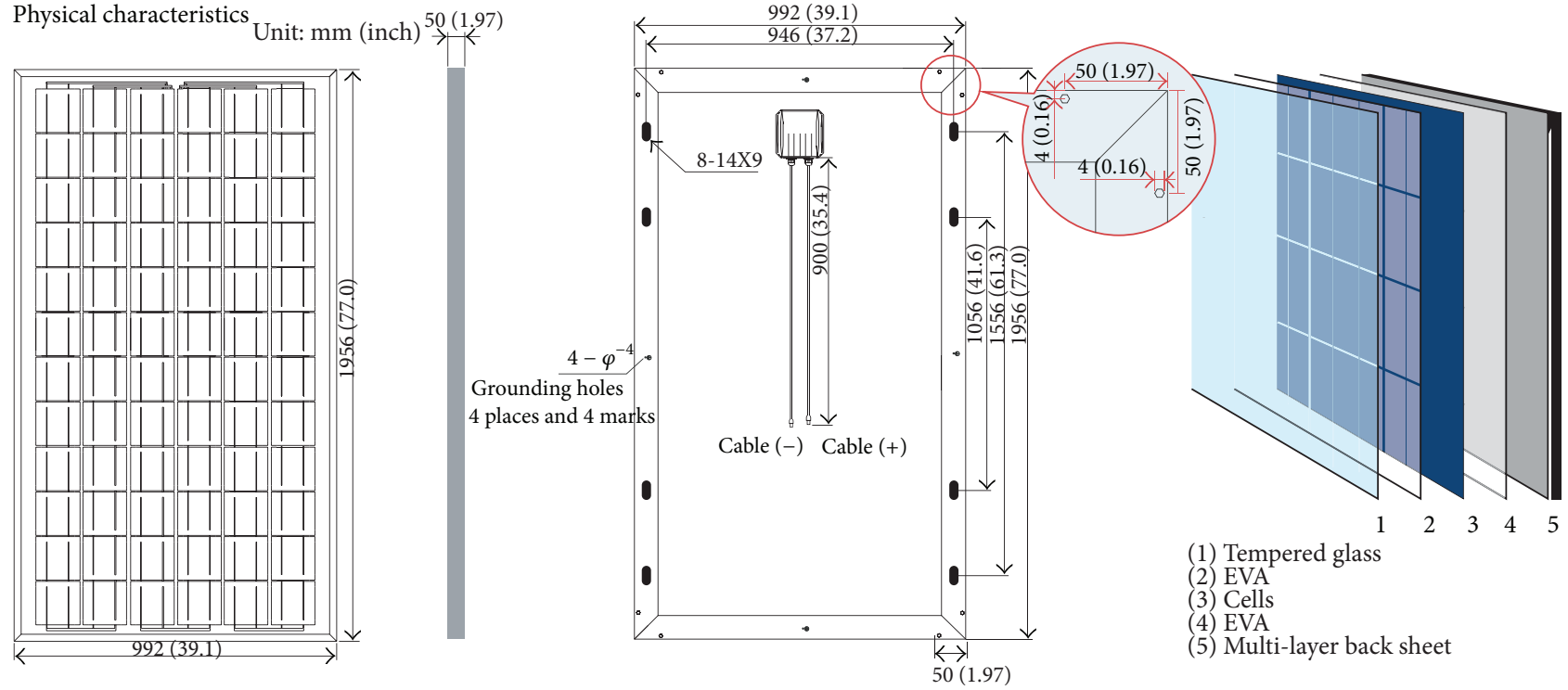

(1) Tempered glass

(2) EVA

(3) Cells

(4) EVA

(5) Multi-layer back sheet

Electrical characteristics
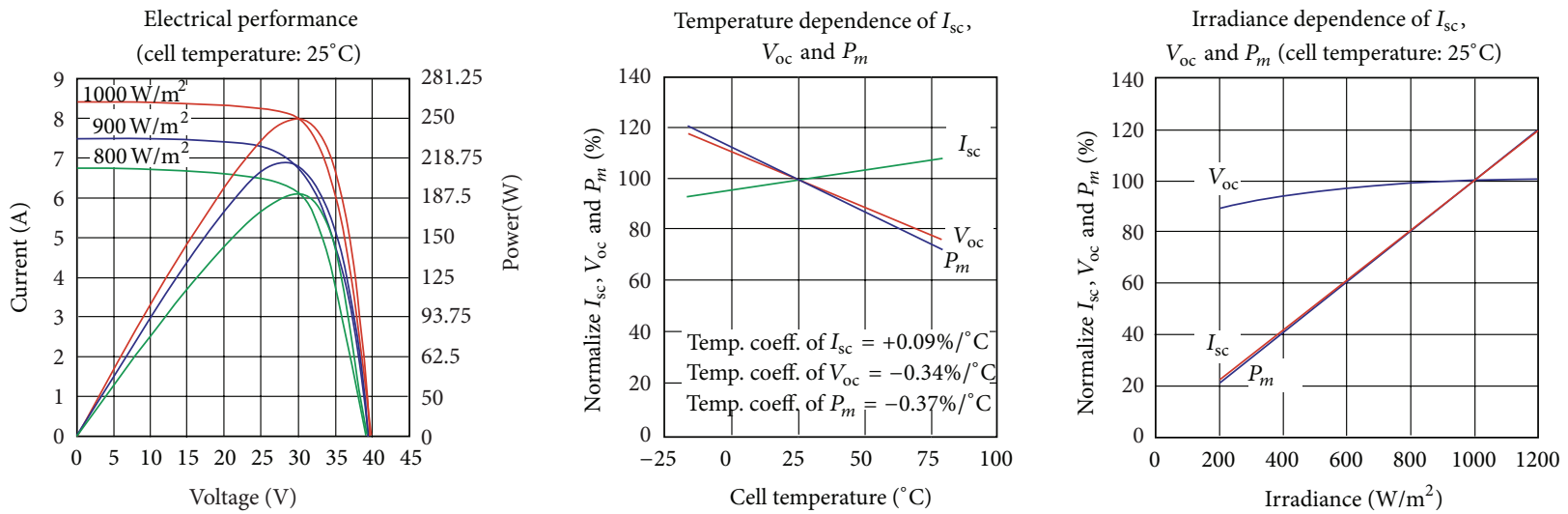

Please contact support@etsolar.com for technical support

FIgURE 2: Specifications of the panels used. 
TABLE 2: Mean values and uncertainty calculated from the uncertainty propagation law [13] for the panel variables.

\begin{tabular}{lcc}
\hline Variable & Mean & Uncertainty \\
\hline$T_{\text {panel, }, 1}$ & $40.0389^{\circ} \mathrm{C}$ & $0.8012^{\circ} \mathrm{C}$ \\
$T_{\text {panel }, 2}$ & $37.2556^{\circ} \mathrm{C}$ & $0.9327^{\circ} \mathrm{C}$ \\
$T_{\text {panel }, 3}$ & $35.3573^{\circ} \mathrm{C}$ & $0.9631^{\circ} \mathrm{C}$ \\
$T_{\text {panel }, 4}$ & $33.8190^{\circ} \mathrm{C}$ & $0.7424^{\circ} \mathrm{C}$ \\
$T_{\text {panel }, 5}$ & $33.8397^{\circ} \mathrm{C}$ & $0.8028^{\circ} \mathrm{C}$ \\
$T_{\text {air }, i, 1}$ & $29.8217^{\circ} \mathrm{C}$ & $0.9242^{\circ} \mathrm{C}$ \\
$T_{\text {air }, i, 2}$ & $29.2886^{\circ} \mathrm{C}$ & $0.9925^{\circ} \mathrm{C}$ \\
$T_{\text {air }, o, 1}$ & $30.1329^{\circ} \mathrm{C}$ & $1.1434^{\circ} \mathrm{C}$ \\
$T_{\text {air }, 0,2}$ & $31.1338^{\circ} \mathrm{C}$ & $1.1813^{\circ} \mathrm{C}$ \\
$v_{\text {air }, 1}$ & $2.1893 \mathrm{~m} / \mathrm{s}$ & $0.0616 \mathrm{~m} / \mathrm{s}$ \\
$v_{\text {air }, 2}$ & $1.1013 \mathrm{~m} / \mathrm{s}$ & $0.0616 \mathrm{~m} / \mathrm{s}$ \\
$I_{\text {pyra }}$ & $535.829 \mathrm{~W} / \mathrm{m}^{2}$ & $9.471 \mathrm{~W} / \mathrm{m}^{2}$ \\
$S_{\text {panel }}$ & $1.7521 \mathrm{~m}^{2}$ & $0.0014 \mathrm{~m}{ }^{2}$ \\
$I_{\text {rr }}^{*}$ & $938.799 \mathrm{~W}$ & $11.1534 \mathrm{~W}$ \\
$V_{\text {mp }}$ & $18.8423 \mathrm{~V}$ & $0.394 \mathrm{~V}$ \\
$I_{\text {mp }}$ & $6.9683 \mathrm{~A}$ & $0.156 \mathrm{~A}$ \\
$P_{m}^{*}$ & $131.248 \mathrm{~W}$ & $3.9203 \mathrm{~W}$ \\
$\eta^{*}$ & 0.14122 & 0.00186 \\
\hline
\end{tabular}

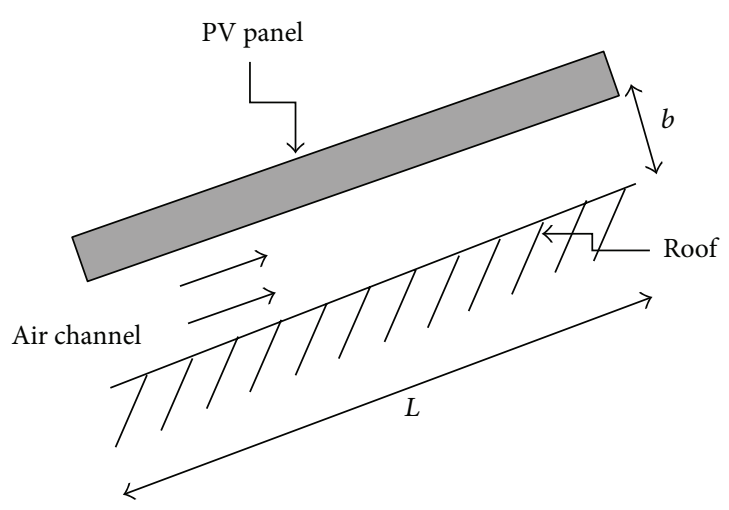

FIGURE 3: Configuration of panel B, showing the air channel between the PV panel and the roof.

has been measured for three different widths of the channel, given by the aspect ratios $(b / L) 0.0525,0.0675$, and 0.0825 .

In the three experimental cases, panel B (which is on the top of steel plate) is warmer than the isolated panel (panel A), so its electrical performance is worse due to the influence of its temperature, even at the highest aspect ratio. Figure 4 shows the temperature gap between each panel and the ambient (Figure 4(a)) and the performance of each panel (Figure 4(b)), which has been measured throughout different sunny days.

When the space of the air channel underneath panel $\mathrm{B}$ is smaller, the temperature difference between panel A and panel $\mathrm{B}$ is higher, up to $8-10^{\circ} \mathrm{C}$ at high irradiance, due to panel $\mathrm{B}$ being less cooled by natural convection and its performance is much worse. However, for the measured highest aspect ratio, the experimental results show that the maximum temperature difference between both panels is 5$6^{\circ} \mathrm{C}$ at high irradiance and panel $\mathrm{B}$ performance is around $0.9 \%$ lower than panel A, as Figure 4 shows.

Therefore, the electrical behaviour of a PV panel placed on a steel roof (such as an industrial building) is affected by high temperature reached by the heat transferred from the steel plate to the panel and a lower cooling effect by natural convection if the space between both surfaces is small. So, this space is an important parameter to consider in these applications; for this reason, we have studied the temperature effect on electrical variables for three air channel thickness.

As mentioned previously, a PV panel placed on a steel roof is warmer than an isolated panel at the same ambient conditions and this panel temperature could be lower depending on the space of the air channel underneath the panel, which leads to lower electrical production. We have tested it for three cases, changing the aspect ratio, as Figure 5 shows. If the aspect ratio increases from 0.0525 to 0.0825 , the panel temperature decreases $5-6^{\circ} \mathrm{C}$ at high irradiance, it is shown from $12.00 \mathrm{~h}$ to $14.00 \mathrm{~h}, \mathrm{GMT}+1$ (Figure 5(a)), so for these times its performance improves around $0.5 \%$ (Figure 5(b)).

However, when the irradiance is lower (at the beginning and end of the day), the aspect ratio does not affect the electrical outputs. It is also explained in Figure 6, showing an influence of the aspect ratio on the electrical variables such as open circuit voltage $\left(V_{\text {oc }}\right)$, short circuit current $\left(I_{\mathrm{sc}}\right)$ and maximum power $\left(P_{\mathrm{mp}}\right)$ for two cases, at high and low irradiance.

In the first case, for an irradiance of $970 \mathrm{~W} / \mathrm{m}^{2}$ (at $13.30 \mathrm{~h}$ ) the open circuit voltage increases when the aspect ratio is higher, the short circuit current decreases and the peak power increases $7.5 \%$ because the panel is cooler and its temperature is lower for high aspect ratio. So electrical production improves when the air space underneath the PV panel increases (Figure 6(a)). On the other hand, for an irradiance of $325 \mathrm{~W} / \mathrm{m}^{2}$ these electrical variables do not vary with the aspect ratio; this fact explains why the panel performance is similar for the three aspect ratios at the beginning and end of the day (Figure 6(b)).

4.3. Forced Convection Cases. Effects of the Aspect Ratio and the Forced Velocity. Having analysed the negative influence of panel temperature on electrical production due to an insufficient air space underneath it, which would allow it to be cooled by natural convection, we have analysed the panel behaviour at forced convection using a fan, for the same previous values of aspect ratio. The forced convection configuration has also been tested at three different forced velocities inside the air channel of 2,3 , and $4 \mathrm{~m} / \mathrm{s}$ (mean velocities of the air flowing into the channel), each one for each width of the air duct. In the results shown below, we have only included two of the forced velocities tested, the minimum and the maximum values $(2$ and $4 \mathrm{~m} / \mathrm{s}$ ), because they are the most significant and show better the differences obtained in the results.

As expected, panel B is much cooler than the isolated reference panel in all the cases and consequently its electrical production is higher, even for the smallest aspect ratio and 


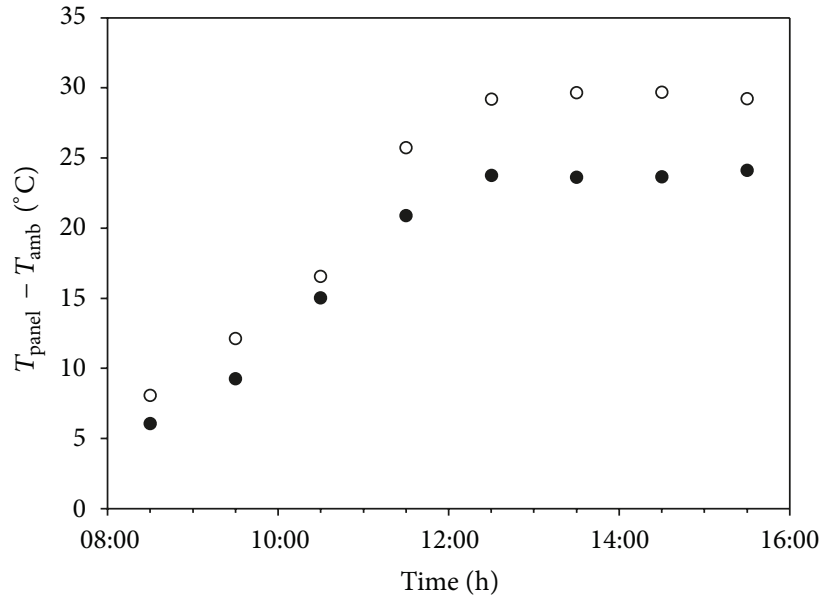

- Panel A

○ Panel B

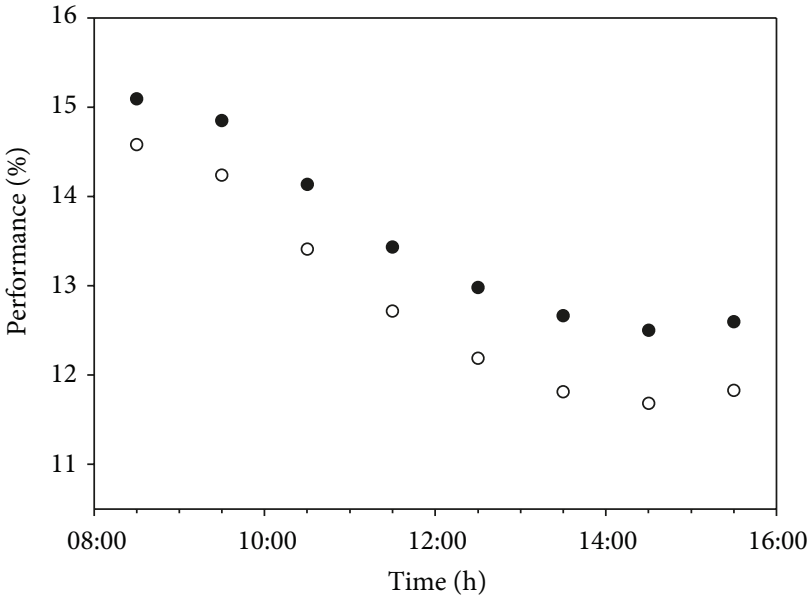

- Panel A

- Panel B

(a)

(b)

Figure 4: Comparison of the behavior between both panels, Panel A and Panel B. (a) Temperature gap between each panel and the ambient. (b) The electrical performance of each panel throughout the day.

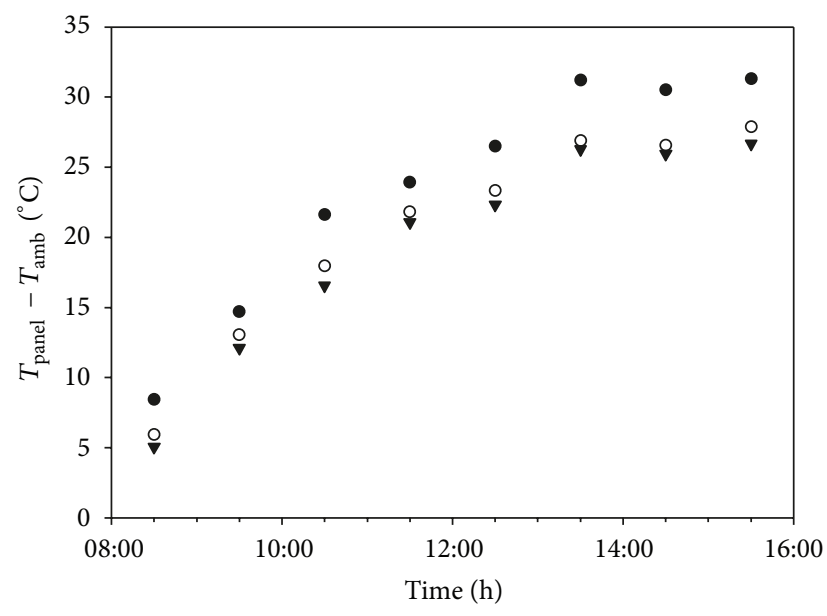

- Natural convection, $b / L=0.0525$

- Natural convection, $b / L=0.0675$

- Natural convection, $b / L=0.0825$

(a)

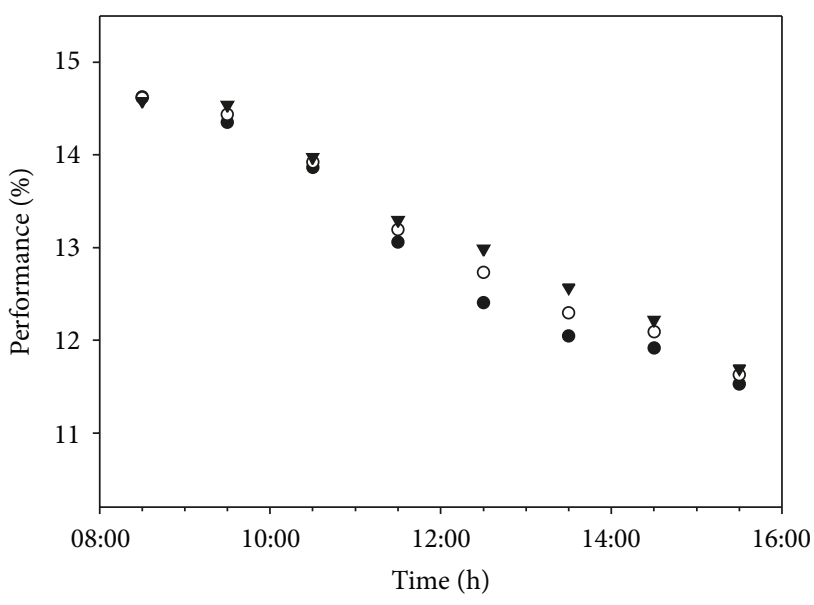

- Natural convection, $b / L=0.0525$

- Natural convection, $b / L=0.0675$

- Natural convection, $b / L=0.0825$

(b)

FIGURE 5: Influence of the aspect ratio at the natural convection configuration. (a) On the panel temperature. (b) On the performance.

the lowest forced velocity, owing to the fact that air by forced convection cools the panel, as Figure 7 shows.

The experimental results also show that the PV panel is cooled more efficiently when the space of air underneath the panel increases, with values of the aspect ratio from 0.0525 to 0.0825 . However, there are hardly any differences between the cases corresponding with $b / L=0.0675$ and those obtained with $b / L=0.0825$, in which the electrical variables are similar.

Comparing both forced velocity cases, we can understand that the temperature difference between the panel and the ambient $7^{\circ} \mathrm{C}$ lower for a forced velocity of $4 \mathrm{~m} / \mathrm{s}$, for each aspect ratio, being as the mass flow inside the air channel is higher and is able to cool the panel better. The heat transfer between the PV panel and the air improves when increasing the air mass flow. This fact happens, on the one hand, when the air forced velocity is higher keeping the same aspect ratio and, on the other hand, enhancing the air channel width at the same forced velocity. The behaviour described is shown in Figure 7.

Hence, the panel reaches the highest temperatures at lower forced velocity and smaller air cross-section; in fact, in these cases the panel performance is lower. When the panel is well cooled (for $V_{f}=4 \mathrm{~m} / \mathrm{s}$ ) the worst performance 


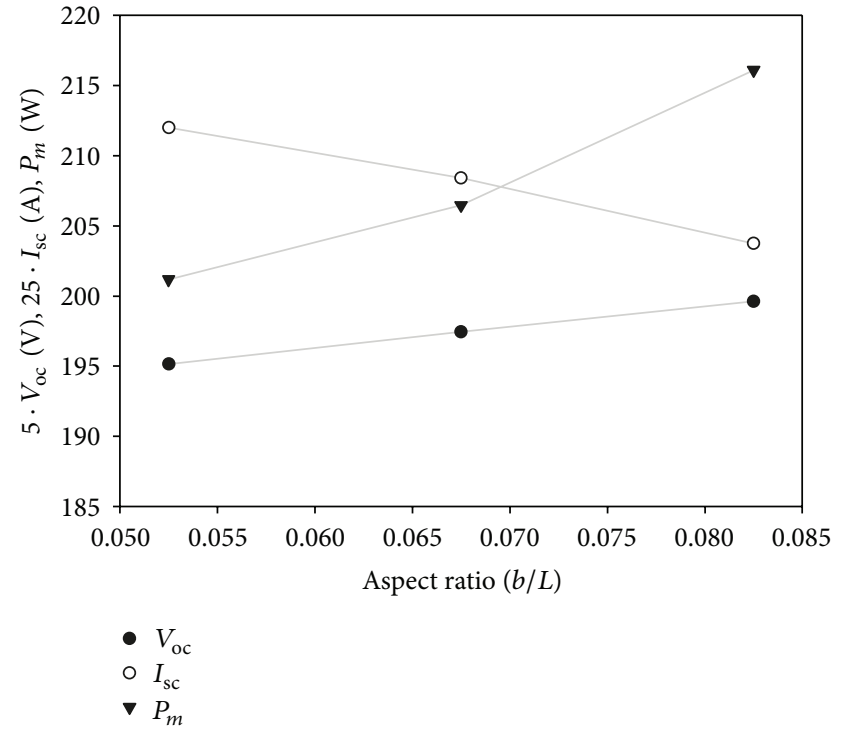

(a)

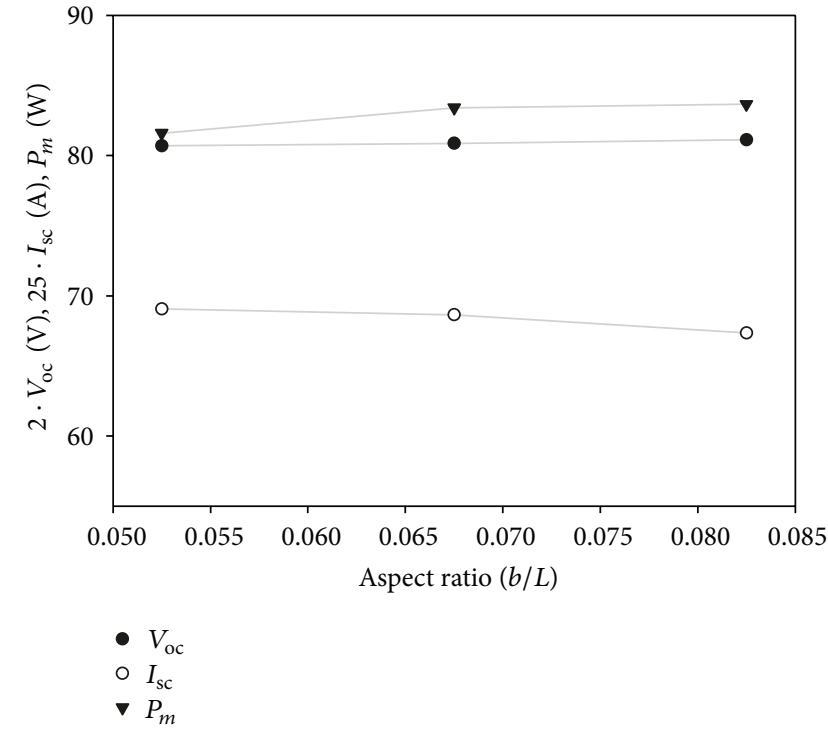

(b)

FIGURE 6: Influence of the aspect ratio on the electrical variables at different ambient conditions. (a) At high irradiance, with $I_{\text {pyra }}=970 \mathrm{~W} / \mathrm{m}^{2}$ and $T_{\mathrm{amb}}^{\mathrm{a}}=29^{\circ} \mathrm{C}$. (b) At medium-low irradiance, with $I_{\mathrm{pyra}}=325 \mathrm{~W} / \mathrm{m}^{2}$ and $T_{\mathrm{amb}}^{\mathrm{a}}=23^{\circ} \mathrm{C}$.

reached is $12.5-13 \%$ depending on the aspect ratio, whereas when the panel is not as well cooled $\left(V_{f}=2 \mathrm{~m} / \mathrm{s}\right)$ the worst performance is $12-12.5 \%$, so the electrical production increases slightly at higher forced velocity. Once the panel is cooled by forced convection, the electrical performance of the panel improves, compared with the results of natural convection shown above, due to the fact that the air-forced convection keeps the panel at lower temperatures.

4.4. Comparison between Natural and Forced Convection Cases for a Given Aspect Ratio. Summarizing what has been shown so far, the panel temperature increases when the panel is placed on a steel plate or roof and its electrical production decreases greatly, especially at high irradiance. This negative effect could be improved by providing an open air channel between both surfaces, which allows the panel to be not as warm because of a better cooling effect on the panel by natural convection. Besides, we have tested that an air channel thickness increase of $0.06 \mathrm{~m}$ reduces the panel temperature up to $5-6^{\circ} \mathrm{C}$ and the electrical efficiency is improved slightly (see Figures 5 and 6). A greater reduction of the panel temperature is achieved by increasing the air mass flow inside the channel by forced convection, so at higher forced velocity and aspect ratio measured, the temperature decrease and the electrical performance improvement is much better with respect to an isolated panel (see Figure 7).

Finally, this study shows the analysis of all results comparing different configurations. As mentioned previously, throughout the day the worst case is at high irradiance, when the panel is warmer and the temperature influence is significant; therefore, the results are compared at these conditions. In abscissa of Figure 8, the mean air velocities through the channel are represented, both for natural convection and forced convection cases.

For a given value of the aspect ratio, the electrical power of a PV panel cooled by forced convection is 3-5\% higher than by natural convection and it increases, as expected, when the forced velocity inside the air duct is higher. The electrical improvement is due to the decrease of PV panel temperature, being of $10-16^{\circ} \mathrm{C}$. Comparing both cases of forced convection, the power increase is of $2.4 \%$ and the panel is $7^{\circ} \mathrm{C}$ cooler at high forced velocity.

For both natural and forced convection cases, the electrical production (power) increases $2-2.5 \%$ with a higher width of the air channel which cools the panel more efficiently, so the panel temperature is $5-7^{\circ} \mathrm{C}$ lower. We can notice that the panel is similar in behavior between the aspect ratios of 0.0675 and 0.0825 because there are hardly any differences in electrical power and panel temperature; hence, the most significant difference has been obtained between the aspect ratio of 0.0525 and 0.0825 ; consequently, we have analysed the negative relationship of the temperature on the performance for these two cases, both at natural and forced convection (see Figure 9).

The experimental results show the negative relationship between the temperature and the electrical performance of a PV panel in all the cases. While the temperature difference between the panel and ambient is not high, there is a slight difference in the performance at different configurations, but when the panel achieves high temperatures, the performance decreases sharply and we can appreciate differences in efficiency depending on the configuration and the aspect ratio.

The minimum values of panel performance are at high panel temperature; if we compare them to the two aspect 

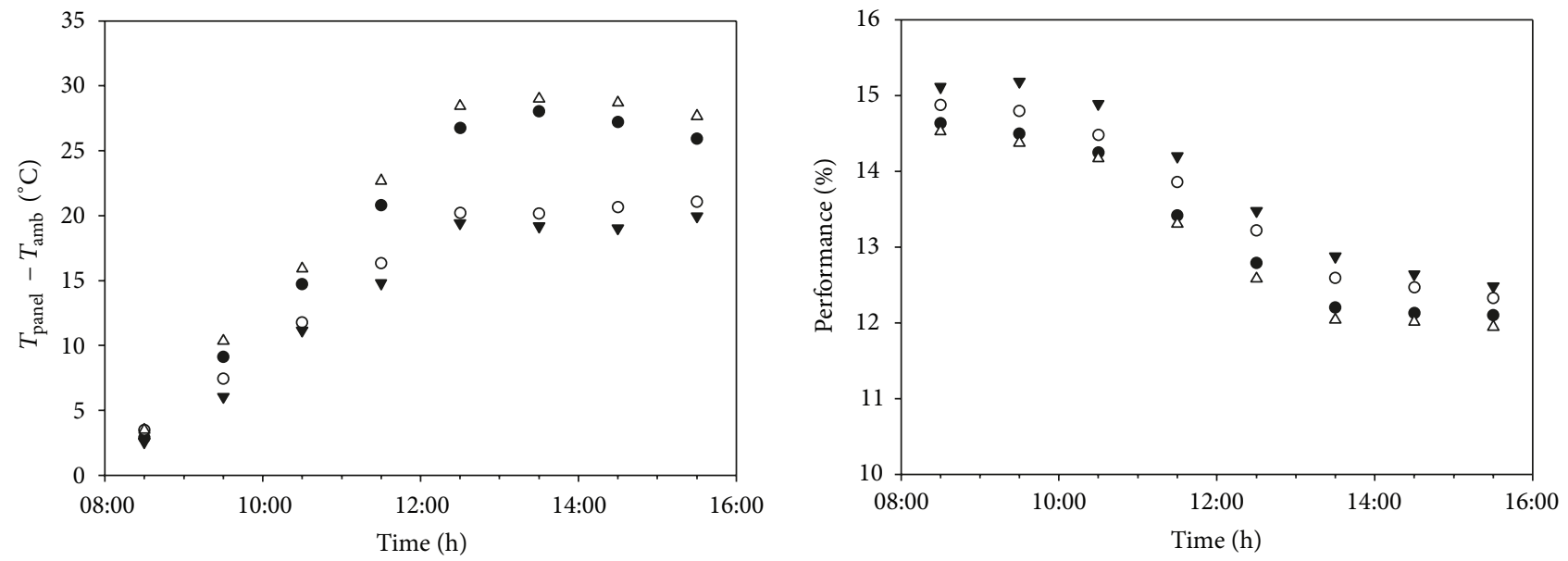

- Forced convection, $V_{f}=2 \mathrm{~m} / \mathrm{s}, b / L=0.0525$

○ Forced convection, $V_{f}=2 \mathrm{~m} / \mathrm{s}, b / L=0.0675$

$\checkmark$ Forced convection, $V_{f}=2 \mathrm{~m} / \mathrm{s}, b / L=0.0825$

$\Delta$ Reference isolated panel A

(a)

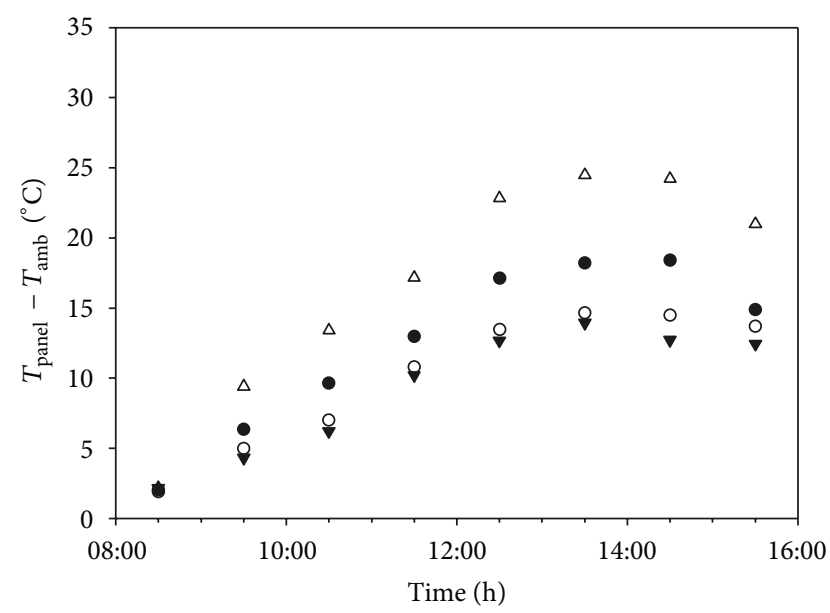

- Forced convection, $V_{f}=4 \mathrm{~m} / \mathrm{s}, b / L=0.0525$

- Forced convection, $V_{f}=4 \mathrm{~m} / \mathrm{s}, b / L=0.0675$

V Forced convection, $V_{f}=4 \mathrm{~m} / \mathrm{s}, b / L=0.0825$

$\Delta$ Reference isolated panel A
- Forced convection, $V_{f}=2 \mathrm{~m} / \mathrm{s}, b / L=0.0525$

- Forced convection, $V_{f}=2 \mathrm{~m} / \mathrm{s}, b / L=0.0675$

- Forced convection, $V_{f}=2 \mathrm{~m} / \mathrm{s}, b / L=0.0825$

$\Delta$ Reference isolated panel A

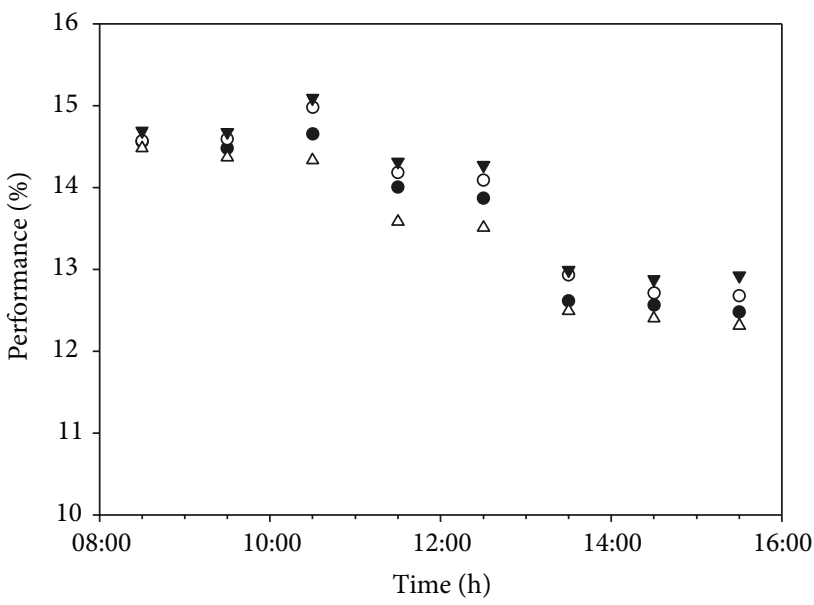

- Forced convection, $V_{f}=4 \mathrm{~m} / \mathrm{s}, b / L=0.0525$

- Forced convection, $V_{f}=4 \mathrm{~m} / \mathrm{s}, b / L=0.0675$

$\checkmark$ Forced convection, $V_{f}=4 \mathrm{~m} / \mathrm{s}, b / L=0.0825$

$\Delta$ Reference isolated panel A

(d)

FIGURE 7: Influence of aspect ratio and forced velocity on the panel temperature and its performance throughout the day. (a) and (b): temperature difference between the panel and the ambient, and panel performance, respectively, for a fan-induced velocity of $2 \mathrm{~m} / \mathrm{s}$. (c) and (d): temperature difference between the panel and the ambient and panel performance, respectively, for a fan-induced velocity of $4 \mathrm{~m} / \mathrm{s}$.

ratios, the minimum performance is higher for the aspect ratio of $b / L=0.0825$ at the different configurations (natural and forced convection), and in this case we can also perceive a greater improvement in the panel performance between the different configurations.

\section{Conclusions}

This work describes the installation built at the Universidad Politécnica de Cartagena to study the use of air as a cooling technique to reduce the temperature of photovoltaic panels and improve their efficiency. The instrumentation used in the analysis has been presented and the uncertainty associated with the measurements has been evaluated. Different configurations have been measured and analyzed to study the influence of the temperature on electrical variables such as power voltage, power current, open circuit voltage, short circuit current, or panel performance. The results have been obtained for both natural and forced convection cases. Three different values of the air channel spacing have been considered throughout this work. 


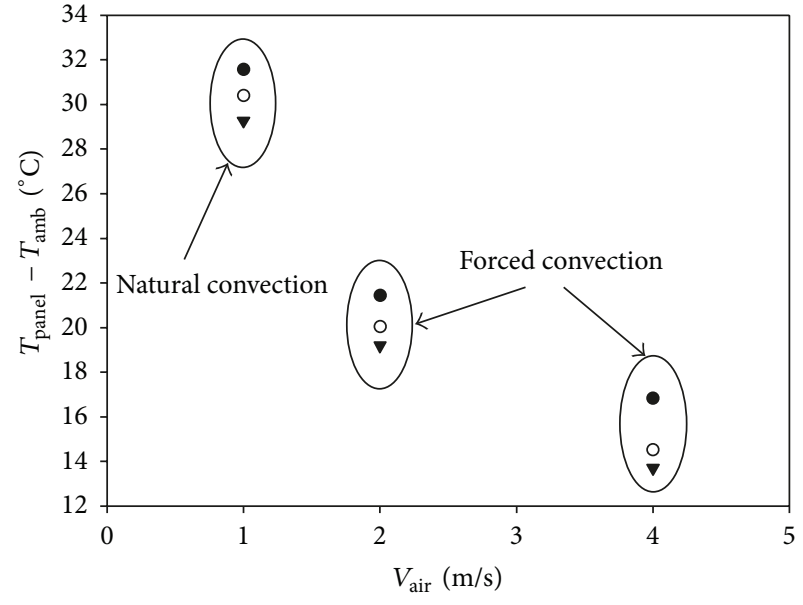

- $b / L=0.0525$

○ $b / L=0.0675$

จ $b / L=0.0825$

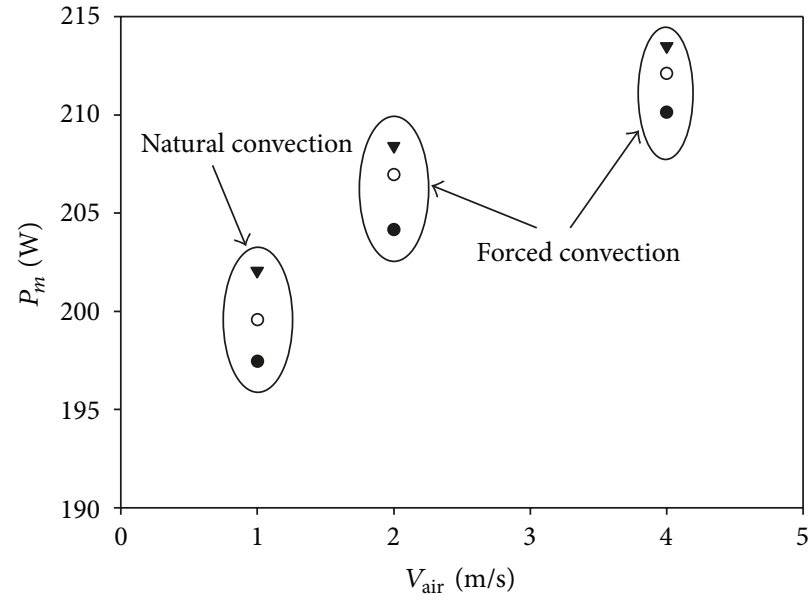

- $b / L=0.0525$

$\circ b / L=0.0675$

、 $b / L=0.0825$

(a)

(b)

Figure 8: Comparison between natural and forced convection cases at different aspect ratios. (a) Peak power. (b) Temperature difference between the panel and ambient.

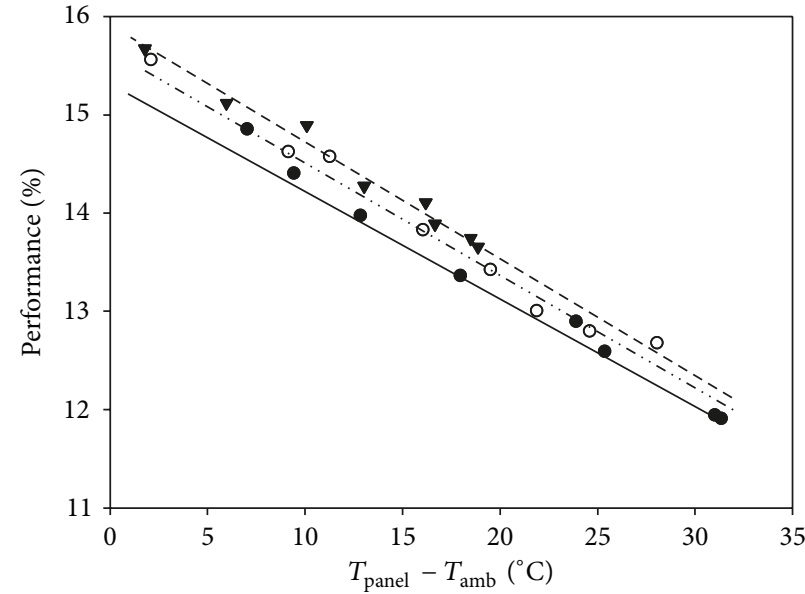

- Natural convection

- Forced convection, $V_{f}=2 \mathrm{~m} / \mathrm{s}$

$\checkmark$ Forced convection, $V_{f}=4 \mathrm{~m} / \mathrm{s}$

(a)

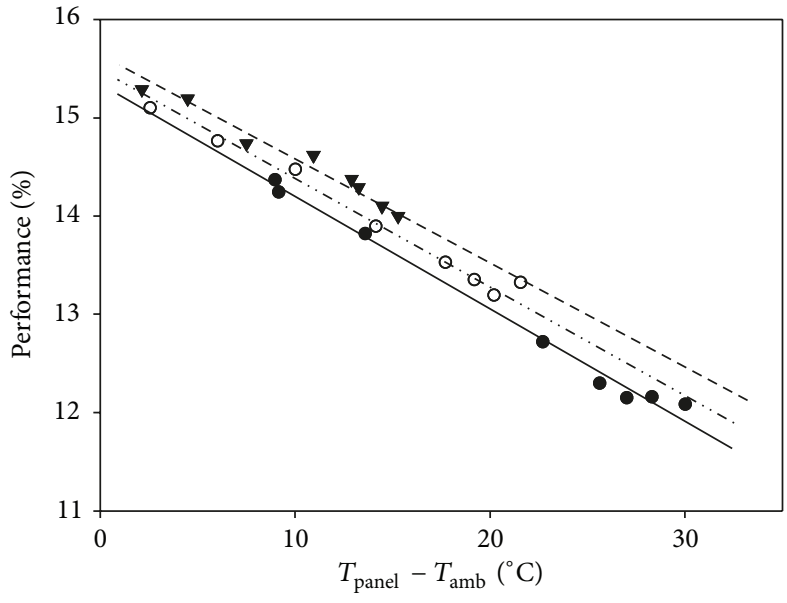

- Natural convection

- Forced convection, $V_{f}=2 \mathrm{~m} / \mathrm{s}$

V Forced convection, $V_{f}=4 \mathrm{~m} / \mathrm{s}$

(b)

FIGURE 9: Relationship between panel performance and panel temperature. (a) For the minimum value of the aspect ratio measured (0.0525). (b) For the maximum value of the aspect ratio measured (0.0825).

The following concluding remarks can be made.

(i) The air space comprised between a photovoltaic panel and a steel roof must be high enough to allow the panel to be cooled and consequently to achieve higher efficiency.

(ii) In the natural convection case, the modified panel (panel B, Figure 1) is warmer than the isolated one (panel A, Figure 1), the temperature difference between panels being higher for the smallest air channel.

(iii) The electrical behaviour of the panels on a steel roof is strongly affected by high temperatures. So, a space between panels and roof is an important parameter to take into account: when the aspect ratio is higher the open circuit voltage increases, whereas the short circuit current decreases, and the peak 
power increases up to $7.5 \%$ because of the lower temperatures.

(iv) In the forced convection case, electrical production is higher in the modified panel than in the isolated one. This is due to the increase in the heat transferred to the air flow by forced convection.

(v) For the same aspect ratio and under the same high irradiance conditions, the electrical power of a panel cooled by forced convection is higher than that obtained by natural convection. Improvements up to $15 \%$ in electrical power and decrease of panel temperature of about $15^{\circ} \mathrm{C}$ have been reported.

\section{Nomenclature}

$b$ : $\quad$ Air channel spacing $(\mathrm{m})$

L: $\quad$ Air channel length (m)

b/L: Aspect ratio

$I_{\mathrm{mp}}$ : Maximum power current (A)

$I_{\text {pyra }}$ : Solar irradiance $\left(\mathrm{W} / \mathrm{m}^{2}\right)$

$I_{\mathrm{rr}}: \quad$ Power irradiance $(\mathrm{W})$

$I_{\text {sc }}: \quad$ Short circuit current (A)

$P_{m}$ : Peak power or maximum power (W)

$S_{\text {panel }}$ : Panel surface area $\left(\mathrm{m}^{2}\right)$

$T_{\text {amb }}$ : Ambient temperature $\left({ }^{\circ} \mathrm{C}\right)$

$T_{\text {panel }}$ : Panel temperature $\left({ }^{\circ} \mathrm{C}\right)$

$V_{\text {air }}:$ Air measured velocity $(\mathrm{m} / \mathrm{s})$

$V_{f}: \quad$ Fan induced velocity $(\mathrm{m} / \mathrm{s})$

$V_{\text {oc }}:$ Open circuit voltage $(\mathrm{V})$

$V_{\mathrm{mp}}$ : Maximum power voltage $(\mathrm{V})$.

\section{Greek Symbols}

$\eta$ : Panel performance.
[4] K. Graff and H. Fischer, "Carrier lifetime in silicon and its impact on solar cell characteristics," Solar Energy Conversion, vol. 31, pp. 173-211, 1979.

[5] J. K. Tonui and Y. Tripanagnostopoulos, "Performance improvement of PV/T solar collectors with natural air flow operation," Solar Energy, vol. 82, no. 1, pp. 1-12, 2008.

[6] S. Krauter, R. G. Araújo, S. Schroer et al., "Combined photovoltaic and solar thermal systems for facade integration and building insulation," Solar Energy, vol. 67, no. 4-6, pp. 239-248, 1999.

[7] E. A. Sweelem, F. H. Fahmy, M. M. Abd-El Aziz, P. Zacharias, and A. Mahmoudi, "Increased efficiency in the conversion of solar energy to electric power," Energy Sources, vol. 21, no. 5, pp. 367-377, 1999.

[8] A. Tiwari, M. S. Sodha, A. Chandra, and J. C. Joshi, "Performance evaluation of photovoltaic thermal solar air collector for composite climate of India," Solar Energy Materials and Solar Cells, vol. 90, no. 2, pp. 175-189, 2006.

[9] M. A. Farahat, "Improvement the thermal electric performance of a photovoltaic cells by cooling and concentration techniques," in Proceedings of the 39th International Universities Power Engineering Conference (UPEC '04), pp. 623-628, September 2004.

[10] S. Krauter, "Increased electrical yield via water flow over the front of photovoltaic panels," Solar Energy Materials and Solar Cells, vol. 82, no. 1-2, pp. 131-137, 2004.

[11] M. Abdolzadeh and M. Ameri, "Improving the effectiveness of a photovoltaic water pumping system by spraying water over the front of photovoltaic cells," Renewable Energy, vol. 34, no. 1, pp. 91-96, 2009.

[12] R. Mazón-Hernández, J.R. García-Cascales, F. Vera-García, A. Sánchez-Kaiser, and B. Zamora-Parra, "Development of an installation to reduce the temperature of photovoltaic modules and improve their efficiency," in Proceedings of the International Conference on Renewable Energies and Power Quality (ICREPQ '10), Granada, Spain, 2010.

[13] "Guidelines for evaluating and expressing the uncertainty of NIST measurement results,” NIST Technical note 1297, 1994.

\section{Subscripts}

$i$ : Inlet

$o$ : Outlet.

\section{Acknowledgments}

The authors thank the local association "Fundación Seneca" for its cooperation in this study, which has been supported by the company Apia XXI, so they would like to show their gratitude to them.

\section{References}

[1] B. J. Brinkworth, B. M. Cross, R. H. Marshall, and H. Yang, "Thermal regulation of photovoltaic cladding," Solar Energy, vol. 61, no. 3, pp. 169-178, 1997.

[2] S. Angrist, Direct Energy Conversion, Allyn and Bacon, Boston, Mass, USA, 1982.

[3] C. Hu and R. White, Solar Cells: From Basic to Advanced System, McGraw-Hill, New York, NY, USA, 1983. 

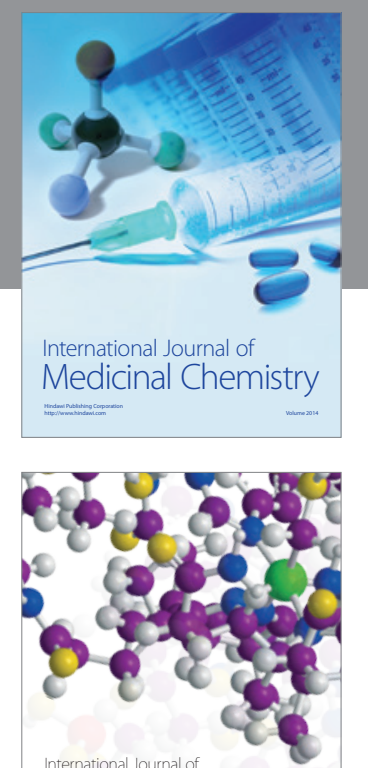

\section{Carbohydrate} Chemistry

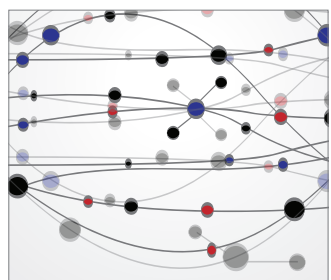

The Scientific World Journal
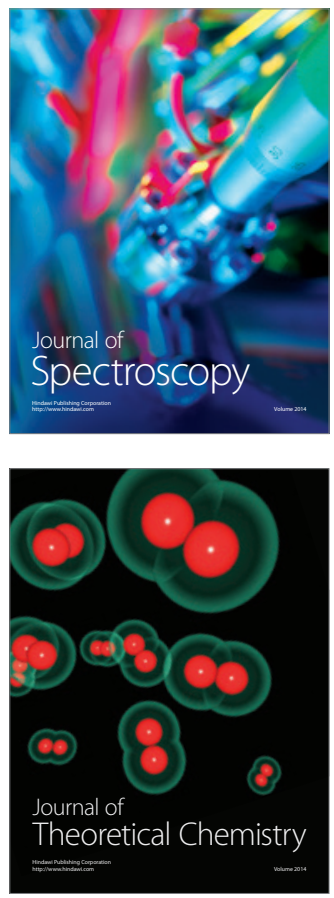
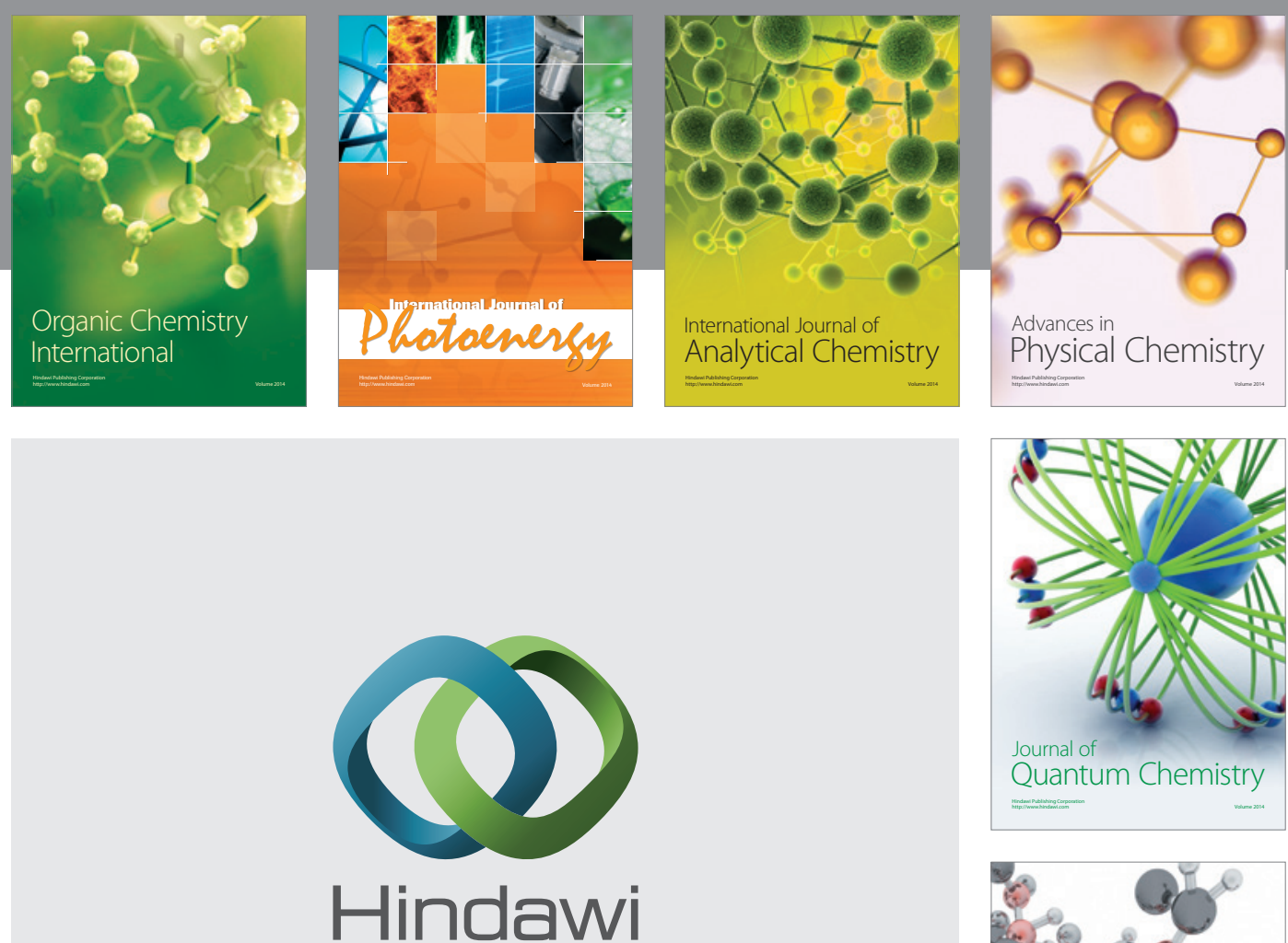

Submit your manuscripts at

http://www.hindawi.com

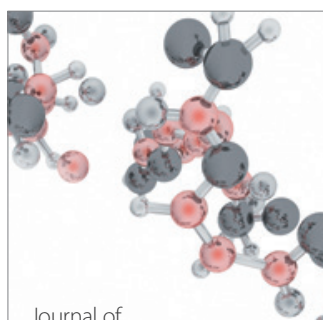

Analytical Methods

in Chemistry

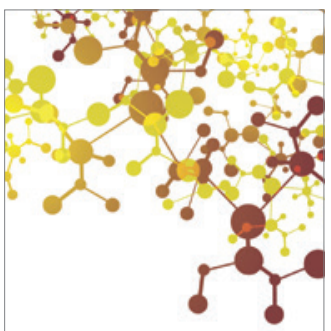

Journal of

Applied Chemistry

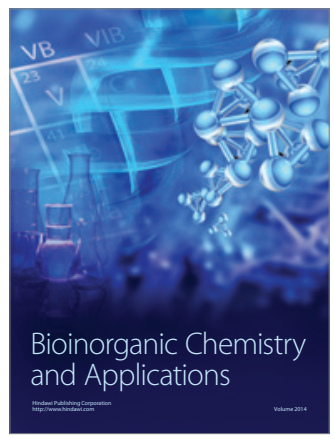

Inorganic Chemistry
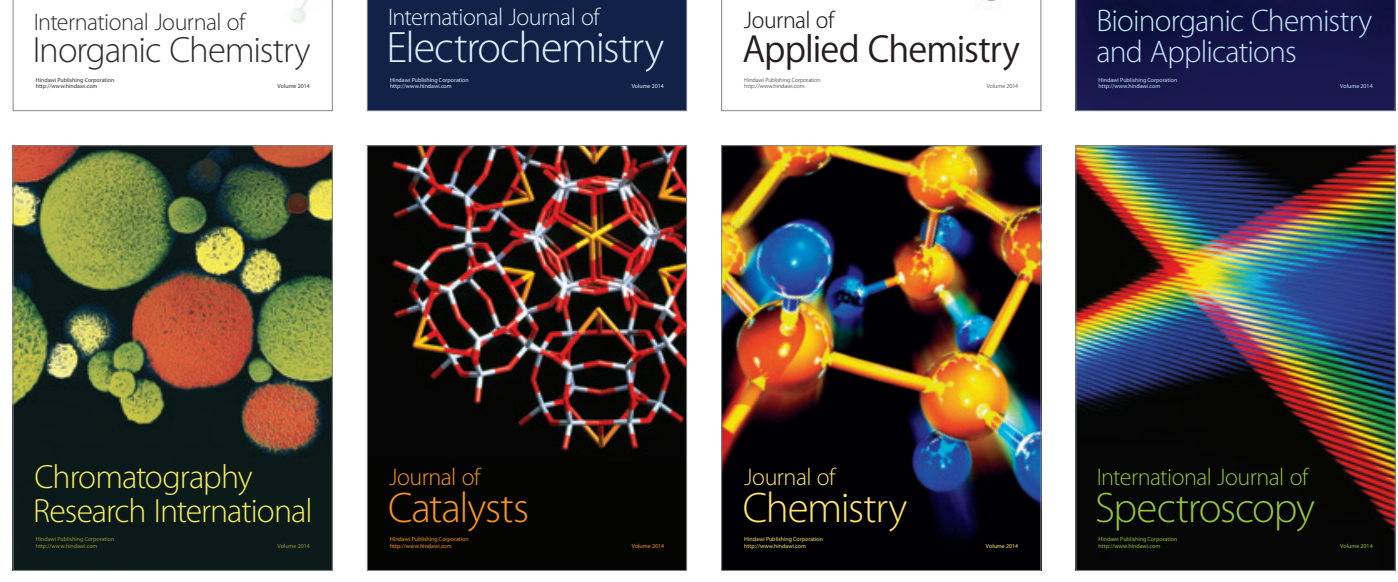